\title{
Is Now the Time for Major Federal Sentencing Reform?
}

Testimony before to Congress in November $201 \mathrm{I}$ and at the Sentencing Commission's February 2012 hearing on Federal Sentencing Options after Booker presented two sharply contrasting views.

In Congressional testimony in November of $20 \mathrm{II}$, the Commission's chair, Judge Patti Saris, advocated legislative changes to (I) require district courts to give "substantial weight" to the Guidelines, (2) require greater justifications for greater variances, (3) apply a more robust standard for appellate review, and (4) apply a heightened standard for review of sentencing decisions based upon

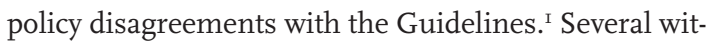
nesses at the Commission's follow-up hearing, including Judge (and former Commissioner) William Sessions ${ }^{2}$ and Professor Frank Bowman, ${ }^{3}$ also called for significant changes in the Guidelines system. Indeed, the structure of the Commission's hearing-which included a panel on Restoring Mandatory Guidelines4_-signaled its interest in such changes. The need for a "Booker fix" rests predominantly (though not exclusively) on the perception of what Judge Saris characterized as "troubling trends in sentencing," meaning declining rates of within-Guidelines sentences and the perception that unwarranted disparity is increasing.

In contrast, however, many other witnesses (myself included) testified that the system is working reasonably well, and they opposed any fundamental legislative changes, particularly those intended to make the system more binding or mandatory. ${ }^{5}$ Some of the witnesses who supported the current advisory Guidelines system urged other changes, particularly the elimination of mandatory minimum sentences and reductions in sentencing severity. ${ }^{6}$

In this brief essay, I explain my view that the Commission's data do not show a "troubling" level of variances and provide no justification for significant legislation changes to reduce judicial discretion and make the federal Guidelines more binding or mandatory.

\section{First Principles}

Proponents of change bear the burden of persuasion. That is true as a general matter, and much more so in the case of such a large and complex system.
Section 3553(a) of the Sentencing Reform Act is the benchmark for evaluating the current sentencing statistics. It begins with a key admonition that courts "shall impose a sentence sufficient, but not greater than necessary" to comply with the statutory purposes of sentencing.7 This parsimony principle is more, not less, important in 2012 than it was at the time of its enactment in I984, because of two well-known factors: the very substantial increase in the size of the federal prison population, and the pressing need to reduce the federal budget deficit.

This is not merely a matter of our concern for the individuals who might serve a term of imprisonment exceeding what the statute requires. In their testimony both Associate Deputy Attorney General Matthew Axelrod ${ }^{8}$ and Professor Frank Bowman 9 rightly called attention to tradeoffs within the criminal justice budget: dollars spent on the Bureau of Prisons are not available for the investigation and enforcement of new criminal activity. Public safety is and should remain a concern, and excessive use of incarceration does not promote public safety.

\section{What does unwarranted disparity mean?}

In considering whether changes are necessary to respond to increasing disparity in the federal system in the wake of the Supreme Court's decision in United States v. Booker, ${ }^{10}$ it is important to consider together two elements of the statutory directive in $\ 3553(\mathrm{a})$.

- Subsection 3553(a)(6) provides that in imposing sentences the courts shall consider "the need to avoid unwarranted sentence disparities among defendants with similar records who have been found guilty of similar conduct."

- However, that provision cannot be considered in isolation. Indeed, Section 3553(a) begins with the admonition in subsection (I) that the court "shall consider ... the nature and circumstances of the offense and the history and characteristics of the defendant."

Read together these provisions demonstrate that a difference in the sentence for two individuals is not an

Federal Sentencing Reporter, Vol. 24, No. 5, pp. 382-386, ISSN 1053-9867 electronic ISSN I533-8363. (C) 2012 Vera Institute of Justice. All rights reserved. Please direct requests for permission to photocopy or reproduce article content through the University of California Press's Rights and Permissions website, http://www.ucpressjournals.com/reprintInfo.asp. DOI: IO.I525/fsr.20I2.24.5.382. 
unjustified disparity if it reflects a difference in the circumstances of the offense, the criminal history of the defendants, or "the characteristics of the defendant."

\section{A. Individual characteristics may warrant different sentences.}

Two recent cases in the United States Supreme Court, Gall v. United States ${ }^{\mathrm{II}}$ and Pepper v. United States, ${ }^{\mathrm{I2}}$ illustrate that not all differences in sentences are unjustified.

As a college student, Brian Gall was using drugs when he joined an ongoing drug conspiracy and delivered ecstasy pills. Within months, however, he stopped using drugs, voluntarily withdrew from the conspiracy, graduated from college, and obtained work in the construction industry, eventually becoming a master carpenter. When federal investigators later approached him, he admitted his limited participation. After release on his own recognizance, Gall started a construction business netting profits of more than \$2,000 per month. Applying the $\ 3553(\mathrm{a})$ factors and noting that Gall had withdrawn from the conspiracy, had used no drugs since college, and was "self-rehabilitated," the district judge sentenced Gall to probation. In considering these factors, the district judge did not create an unwarranted disparity between Gall and other offenders. To the contrary, the disparity was warranted. In reviewing the case, the Supreme Court held that "[o]n abuse-of-discretion review, the Court of Appeals should have given due deference to the District Court's reasoned and reasonable decision that the $\int 3553$ (a) factors, on the whole, justified the sentence." ${ }^{13}$

In the Supreme Court, Jason Pepper's case involved the issue, not relevant here, of the propriety of considering post-rehabilitative resentencing. For my purposes, the main point is how much Jason Pepper, like Brian Gall, differed from most offenders sentenced for similar offenses. By the time of his resentencing on drug charges, Pepper was no longer a drug addict, was enrolled in community college, had achieved very good grades, was working part time, and was slated for a promotion. He was married and supporting a family, and had also reestablished relationships with his father. His probation officer testified that in light of his substantial assistance and rehabilitation, Pepper posed a very low risk of reoffending. Under I8 U.S.C. \3553(a)(I) the sentencing court was not merely permitted, but required to consider these factors. Given Pepper's characteristics and the statutory directive to impose a sentence not greater than necessary to satisfy the statutory purposes of sentencing, it was entirely appropriate for the district court to sentence him very substantially below the Guidelines range. Thus the difference between Pepper's sentence and that of other defendants whose conduct involved the same quantity of drugs is not an unjustified disparity. Indeed, it would be counterproductive to require that he be imprisoned for as long as another offender who had neither conquered his addiction nor demonstrated such exemplary rehabilitation.
These cases illustrate how critical it is not to equate all sentences below the Guidelines range with unwarranted and "troubling" disparity. Below-Guidelines sentences may be fully in accordance with both the mandate of the parsimony principle as well as the statutory requirement that the district courts consider the offender's characteristics. Advocates of changes that would make the federal system more binding, moving it closer to a mandatory system, typically emphasize the increasing percentage of below-Guidelines sentences not sponsored by the Government. This argument assumes that these variances and departures are unwarranted in some, most, or all of the individual cases. ${ }^{14}$ That assumption, however, is not consistent with the statutory directives.

One of the changes proposed by Judge Saris on behalf of the Commission would work an important, and undesirable, change on this very point. In her Congressional testimony in October 20II, Judge Saris suggested that the language of $\llbracket 3553(\mathrm{a})(\mathrm{I})$ should be modified to eliminate the reference to offender characteristics in the sentencing of individual defendants. ${ }^{15}$ Gall, Pepper, and many other cases demonstrate the importance of consideration of offender characteristics in individual cases.

\section{B. Sentencing Discretion and Differences in Prosecutorial Charging and Bargaining}

The additional flexibility provided to the district courts as a result of the Booker decision also provided these courts with an enhanced ability to achieve greater consistency (rather than disparity) by offsetting variances in prosecutorial practices. ${ }^{16}$

The Commission's data have consistently shown significant differences from district to district, which were present both before and after the Booker decision. As Professor Michael Tonry noted in his prepared testimony, sentencing regimes in the U.S. (as elsewhere) will exhibit natural regional variations. ${ }^{77}$ What Professor Tonry did not emphasize is how much of the variation from district to district has been and continues to be the result of differences in the policies and practices of the U.S. Attorney's Offices, particularly with regard to the prevalence and standards for downward departures for substantial assistance. In 2010 , the rate of government-sponsored downward departures for substantial assistance in six profiled districts ranged from a low of 2.8 percent to a high of 32 percent. ${ }^{18}$ Equally important, this variation in prosecutorial practices existed both before and after Booker, with the same districts having very low or high rates of substantial assistance departures. ${ }^{19}$

Additionally, the Commission's mandatory minimum studies have revealed long-standing practices that may create disparity. The Commission's 20II report to Congress on mandatory minimums documented that inconsistent charging and plea practices among districts resulted in the disparate application of mandatory minimum sentencing provisions. ${ }^{20}$ Similarly, in I995, the Commission found that less than half of defendants eligible for mandatory 
sentencing under 18 U.S.C. \924(c) were sentenced under that provision. No charges under $\int 924$ (c) were ever filed in a significant number of eligible cases, and in many other cases the $\int 924$ (c) charges were bargained away in plea negotiations. ${ }^{2 \mathrm{I}}$

A new working paper describing a study by Professors Sonja Starr and Marit Rehavi highlights how critical it may be to study the effect of charging decisions and to maintain judicial flexibility. ${ }^{22}$ Their working paper reports their conclusion that black arrestees, especially black males, face significantly more severe charges conditional on the offense for which they are arrested and other observed characteristics. They find that the disparity in the use of charges that carry mandatory minimum sentences is "particularly striking," and disparities arising from charging decisions "appear to be major drivers of sentencing disparity." ${ }^{23}$ Accordingly, they suggest that "if policymakers are serious about reducing racial disparity in sentencing, a substantial portion of their focus should be on the role of prosecutorial discretion, including the application of mandatory minimum sentences." ${ }^{24}$ Although this is merely a working paper, it shows the potential impact of charging decisions, as well as the wisdom of preserving judicial flexibility.

Prosecutorial charging decisions are not made transparently and are not subject to judicial review. It seems unwise to focus on reducing judicial discretion-but not disparities in prosecutorial practices-when doing so may deprive the courts of a tool to respond to prosecutorial practices and promote true sentencing uniformity.

\section{Conclusions about Disparity}

These general observations lead me to two conclusions. First, the data do not show unwarranted sentencing disparity (though there are significant problems with a few particular Guidelines, some of which are under review by the Commission). In my view, these data are not sufficient to meet the burden of demonstrating the need for fundamental change. Although the system that has evolved since Booker is not perfect, the district courts now have the flexibility to respond in individual cases to excessively (or insufficiently) severe sentences that do not serve the statutory purposes of sentencing. Second, it is unclear whether any of the proposed changes would achieve the goal of reducing unwarranted disparity. Reducing downward departures and variances might actually increase true disparity by eliminating judicial flexibility to take into account critical offender characteristics and to offset differences in prosecutorial practices and policies.

What if the Commission or other groups produce more refined data showing increases in regional and inter-judge disparity? ${ }^{25}$ What should we do if judges in some regions, or individual judges on some courts, are consistently more willing than others to sentence below the Guidelines when there are factors that might support such a sentence under \3553(a)? In considering whether statutory changes are warranted, we should recognize that there may be good reasons for regional variations. Sentences within certain districts or regions may reflect distinctive local conditions, including prevalence of certain crimes, the charging practices of the U.S. Attorneys, the federal caseload, and the availability of state prosecutions. ${ }^{26}$ Such disparity is not unwarranted. And we should also be wary of any cure that may be worse than the disease. In this context, what critics call "disparity" generally means an uneven distribution of sentences that are below (not above) the applicable Guidelines range. Unwarranted severity can produce sentencing disparity. ${ }^{27}$ I argue below that excessive sentence severity is a problem, but not one that Congress is likely to solve, at least in the near term. If I am right, reducing so-called disparity in this context will mean increasing unwarranted severity.

\section{Assessing Other Justifications for Change}

The hardest question to answer is how to assess the proposals for fundamental change ably championed by Judge Sessions, ${ }^{28}$ Professor Frank Bowman, ${ }^{29}$ and the Constitution Project. ${ }^{\circ}$

To say that the current system is working fairly well is not to say that it is ideal. I agree that we could in theory have a much better-or even an ideal—system. My wish list for a new or improved sentencing regime would include:

- recalibration to lower sentences, because the present system generates unnecessarily severe sentences that impose great costs on society as well as individual offenders, their families, and communities;

- simplification, because the present system is unduly complex, making it more costly and more prone to error;

- enhanced reliability of fact-finding on key factual issues;

- preservation of judicial flexibility, which might include but would not be limited to broader sentencing ranges;

- insulation from Congressional micro-management; and

- correction of structural problems, such as the fact that the Sentencing Commission is not subject to the rule-making procedures and appellate review under the Administrative Procedure Act. ${ }^{31}$

The question, however, is not whether one can imagine a better system, but whether now is the time to initiate the process for fundamental change and redesign of the federal sentencing system.

There is no present agreement on the key goals or elements of change. As noted, some advocates of change seek a system that is mandatory (or as close to mandatory as constitutionally possible without jury findings). Others, however, have very different goals, giving a high priority to bringing sentencing levels down, simplifying the system, and preserving judicial flexibility. 
The choice among those alternatives would not be made by the Sentencing Commission and the witnesses who testified before it, or by the specialists who read the Federal Sentencing Reporter. Any changes of this nature would necessarily require Congressional action.

Congress is - and is intended to be-a political, nonexpert, lay body. It does not approach sentencing from the perspective of those who work in the system day to day, seeing the individual cases like Gall and Pepper, nor from an academic perspective. Its views of needed and desirable change in the past twenty years have focused on two elements: harsher sentences and less judicial discretion. ${ }^{32}$ These themes have been popular with the public.

What basis do we have for thinking this dynamic will change? Why should we think that the views of the Commission or experts will be more persuasive in Congress now?

Two time-worn adages contain wisdom that seems very much on point here. The first is the old trial lawyers' adage that you should never ask a witness a question if you don't already know the answer. There's a rough parallel here. We should not ask Congress for fundamental reform of the sentencing process if we don't know what answer it might give to the question how the system should change. The second adage is often attributed to Voltaire: the perfect is the enemy of the good. The witnesses who cautioned the Sentencing Commission against change have concluded that the present system, though far from perfect, is pretty good. That is especially so when contrasted with a system that combines inflexibility with excessive severity.

I agree.

\section{Notes}

1 See Judge Patti B. Saris, Testimony before the Subcommittee on Crime, Terrorism, and Homeland Security, House Judi. ciary Committee, October 12, 2011, 24 FED. SENT'G REP. 344 (2012).

2 See Written Statement of Judge William K. Sessions III, District Judge, District of Vermont, available at http://www.ussc. gov/Legislative_and_Public_Affairs/Public_Hearings_and_ Meetings/20120215-16/Testimony_16_Sessions.pdf.

3 See Testimony of Professor Frank O. Bowman, Floyd R. Gib. son Missouri Endowed Professor of Law, University of Missouri School of Law, available at http://www.ussc.gov/ Legislative_and_Public_Affairs/Public_Hearings_and_Meetings/20120215-16/Testimony_16_Bowman.pdf .

4 See U.S. Sentencing Commission, Public Hearing on Federal Sentencing Options after Booker, Feb.16, 2012, Washington, DC, available at http://www.ussc.gov/Legislative_and_Public_ Affairs/Public_Hearings_and_Meetings/20120215-16/ Agenda_16.htm.

5 See, e.g., Written Statement of Douglas J. Berman, Seeking to Fix What's Obviously Broke in the Post-Booker Federal Sentencing System, available at http://www.ussc.gov/Legislative_and_ Public_Affairs/Public_Hearings_and_Meetings/20120215-16/ Testimony_16_Berman.pdf (concluding the post-Booker system is "pretty sound," but recommending focus on unwarranted severity, reform of problematically harsh Guidelines, and improving procedural fairness in the sentencing process); Testimony of David Debold, Chair, Practitioners Advisory Group, available at http://www.ussc.gov/Legislative_
and_Public_Affairs/Public_Hearings_and_Meetings/20120215-16/Testimony_16_PAG.pdf (concluding "the system is working well" and opposing changes in appellate review and greater justification for greater variances); James E. Felman, Testimony on Behalf of the American Bar Associa tion before the U.S. Sentencing Commission, February 16, 2012, 24 FED. SENT'G REP. 369 (2012) (concluding that the advisory Guidelines system best achieves the goals of the Sentencing Reform Act and opposing mandatory Guidelines); Statement of Chief United States Circuit Judge Theodore McKee, Court of Appeals for the Third Circuit, on Behalf of the Judicial Conference of the United States Committee on Criminal Law, available at http://www.ussc.gov/Legislative_ and_Public_Affairs/Public_Hearings_and_Meetings/20120215-16/Testimony_16_McKee.pdf (concluding that "the current advisory system is fair, workable, transparent, predictable, and flexible," and finding "no need for major sentencing reform"); Statement of Michael Nachmanoff, Fed. eral Public Defender for the Eastern District of Virginia, available at http://www.ussc.gov/Legislative_and_Public_ Affairs/Public_Hearings_and_Meetings/20120215-16/ Testimony_16_Nachmanoff.pdf (concluding that "no Booker fix is necessary" and opposing mandatory Guidelines"); State ment of Mary Price, Vice President and General Counsel, FAMM, available at http://www.ussc.gov/Legislative_and_Pub lic_Affairs/Public_Hearings_and_Meetings/20120215-16/ Testimony_16_FAMM.pdf (concluding that proposals to make the Guidelines mandatory or more binding rest on "flawed premises, missing information, unduly rigid interpretations of the role of the Guidelines in sentencing, and the failure to recognize-or at least help Congress recognize-the difference between disparity that is warranted and that which is not"); Written Statement of Lisa Wayne, President, on Behalf of the National Association of Criminal Defense Lawyers, available at http://www.ussc.gov/Legislative_and_Public_Affairs/Public_ Hearings_and_Meetings/20120215-16/Testimony_16_ NACDL_Wayne.pdf (supporting the advisory Guidelines system and opposing the Commission's proposals).

6 See, e.g., Statement of Honorable Judge Andre M. Davis, United States Circuit Judge, United States Court of Appeals for the Fourth Circuit 1-3, available at http://www.ussc.gov/ Legislative_and_Public_Affairs/Public_Hearings_and_Meetings/20120215-16/Testimony_16_Davis.pdf (criticizing effect of mandatory minimum sentencing statutes; calling on Congress to reassess the severity, scope, and structure of recidivist provisions; and supporting expansion of the safety valve provisions); and Felman, supra note 5, at 369-70, 371 (describing the problem of excessive reliance on incarcera. tion and sentencing severity, and opposing mandatory minimum sentences).

$7 \quad 18$ U.S.C. $\S 3553(a)$.

8 Matthew Axelrod, Testimony on Behalf of the U.S. Department of Justice before the U.S. Sentencing Commission, February 16, 2012, 24 Fed. Sent'g Rep. 348, 348-49 (2012).

9 Statement of Professor Frank O. Bowman, supra note 3, at 19.

10543 U.S. 220 (2005).

11552 U.S. 38 (2007).

12131 S.Ct. 1229 (2011).

13552 U.S. at 59-60.

14 The real question is what offender characteristics are relevant to sentencing. Not all are. Even members of the Supreme Court who disagree on other issues agree that giving harsher sentences to Red Sox fans than to Yankees fans would be improper and warrant reversal on appeal. Justice Stevens stated that "a district judge who gives harsh sentences to Yankee fans and lenient sentences to Red Sox fans would not be acting reasonably even if her procedural rulings were 
impeccable." Rita v. United States, 351 U.S. 338, 364 (Ste vens, J., concurring). Justice Scalia argued that a reasonableness review cannot contain a substantive component, but that it would be a procedural error to rely on an improper factor like sports team affiliation. Id. at 382 (Scalia, J., concurring in part and concurring in the judgment). But why assume that judges in all below-Guidelines cases are relying on irrelevant factors like sports loyalties, rather than highly pertinent characteristics like those in Gall and Pepper?

15 Judge Saris suggested that this change was necessary to eliminate the perceived tension between $\S 3553(a)(1)$ and 28 U.S.C. § 994(e), which instructed the Commission not to base the Guidelines on certain offender characteristics. Saris, supra note 1 . The function of the Commission and the individual sentencing judge differ, and I see no inconsistency requiring a legislative change.

16 See Statement of Raymond Moore, Federal Public Defender for the Districts of Colorado and Wyoming, Current State of Federal Sentencing, at 31-32, available at http://www.ussc. gov/Legislative_and_Public_Affairs/Public_Hearings_and Meetings/20120215-16/Testimony_16_Moore.pdf (challenging Commission's charge that disparities among dis tricts and circuits are increasing because it ignores wide variation in government-sponsored departures and variances).

17 Summary of Testimony, U.S. Sentencing Commission, Michael Tonry, Professor of Law and Public Policy, University of Minnesota, at 4, available at http://www.ussc.gov/Legisla. tive_and_Public_Affairs/Public_Hearings_and_Meetings/ 20120215-16/Testimony_16_Tonry.pdf.

18 Id. at fig. 3.

19 Id. at figs. 2, 3

20 See U.S. Sentencing Commission, Report to Congress: Mandatory Minimum Penalties in the Federal Criminal Justice System 345-46, 368 (Oct. 2011).

21 Sara Sun Beale, The Unintended Consequences of Enhancing Gun Penalties: Shooting Down the Commerce Clause and Arming Federal Prosecutors, 51 Duke L.J . 1641, 1676-78 (2002).

22 M. Marit Rehavi \& Sonja B. Starr, Racial Disparity in Federal Criminal Charging and Its Sentencing Consequences (January $15,2012)$, University of Michigan Law \& Economics, Empirical Legal Studies Center Paper No. 12.002, available at http:// ssrn.com/abstract $=1985377$
23 Id. (abstract).

24 ld. at 5.

25 It is questionable whether the Commission's data do pres. ently show an increase in inter-circuit and inter-judge disparity. See Letter of Thomas W. Hillier to Hon. F. James Sensenbrenner \& Hon. Robert C. (Bobby) Scott, Re: Hearing on "Uncertain Justice: The Status of Federal Sentencing and the U.S. Sentencing Commission Six Years After U.S. v. Booker," at 7-12 (Oct. 11, 2011), available at http://democrats.judiciary.house.gov/sites/democrats.judiciary.house. gov/files/Hillier111011.pdf (arguing that Commission has offered neither meaningful analysis of the differences among districts nor evidence of increasing or unwarranted differences); and Statement of Raymond Moore, supra note 16 , at 31 (noting research finding variation in sentence length after Booker to be less than variation before the PRO. TECT Act and only slightly more than after the PROTECT Act).

26 Id. at 33-35 (discussing many varied sources of regional disparity).

27 See Written Statement of Douglas J. Berman, supra note 5, at 4-5 (discussing the connection between unwarranted severity and disparity).

28 See Written Statement of Judge William K. Sessions, supra note 2.

29 See Testimony of Professor Frank O. Bowman, supra note 3.

30 See The Constitution Project, Recommendations for Federal Criminal Sentencing in a Post-Booker World (2006), available at http://www.constitutionproject.org/pdf/33.pdf; and The Constitution Project, Principles for the Design and Reform of Sentencing Systems: A Background Report (2005).

315 U.S.C. $\S \S 551-59,701-6$.

32 See Written Statement of Douglas J. Berman, supra note 5, at 6 (describing frequent enactment of mandatory minimum sentencing provisions as well as the Feeney Amendment to Protect Act); and Susan R. Klein \& Sandra Guerra Thompson, DOJ'S Attack on Federal Judicial Leniency, The Supreme Court's Response, and the Future of Federal Sentencing, 44 TuLSA L. Rev. 519, 529-35 (2009) (describing enactment of the Sar. banes Oxley Act and the Feeney Amendment). 